\title{
Description of the zoeal stages of Periclimenes aegylios Grippa \& d'Udekem d'Acoz, 1996 (Crustacea: Decapoda: Palaemonidae) reared in the laboratory
}

\author{
GIORGIA DI MUZIO ${ }^{1}$, RITA BASILE ${ }^{2} \&$ DANIELA PESSANI ${ }^{1}$ \\ ${ }^{1}$ Laboratorio di Zoologia e Biologia Marina (LBMT) - Dipartimento di Scienze della Vita e Biologia dei Sistemi, Via Accademia \\ Albertina 13,10123 Torino (Italy).E-mail: giorgia.dimuzio@unito.it daniela.pessani@unito.it \\ ${ }^{2}$ Fondazione Esperienze di Cultura Metropolitana - Piazza della Libertà 4, 10036 Settimo Torinese (Torino, Italy). \\ E-mail: rita.basile@fondazione-ecm.it
}

\begin{abstract}
The eight zoeal stages of the Mediterranean shrimp Periclimenes aegylios are described and illustrated in detail, using laboratory-reared specimens. This study improved the partial and unpublished descriptions of the zoeae of this species. The complete and accurate definition of the morphology of all the stages now allows comparison of the zoeae of $P$. aegylios with those of other Mediterranean Periclimenes species, as well as the allopatric Atlantic P. sagittifer, from which $P$. aegylios was separated in 1996.
\end{abstract}

Key words: Larval morphology, Mediterranean Sea, sagittifer complex, species comparison

\section{Introduction}

Although recent restriction and reviews refer to the genus Periclimenes O.G. Costa, 1884 as a polyphyletic taxon (Bruce et al. 2005; Bruce 2007), it remains a particularly speciose genus of Palaemonidae (Crustacea: Decapoda), with over 155 species (Bruce 2007; Li 2009), being widely distributed throughout the oceans. Some species are reported as free-living, whereas other species are found in association with a variety of invertebrate taxa, including sponges, cnidarians, molluscs, or echinoderms.

In the Mediterranean Sea, the genus is represented by six species (De Grave \& Fransen 2011; Koukouras \& Türkay 1996; d'Acoz 1999), namely P. scriptus (Risso, 1822), P. amethysteus (Risso, 1827), P. kornii (Lo Bianco, 1903), P. granulatus Holthuis, 1950, P. aegylios Grippa \& d'Udekem d'Acoz, 1996, and P. eleftherioui Koukouras \& Türkay, 1996.

Periclimenes aegylios was separated from the Atlantic P. sagittifer (Norman, 1861) in 1996 (Grippa \& d'Acoz 1996), firstly as a subspecies and then accepted as a species, due to a significant distinctive colouring pattern of the adults. Authors suggested that the two species, part of the sagittifer complex, are allopatric; $P$. sagittifer has an Atlantic distribution while $P$. aegylios is considered endemic to the Mediterranean Sea. P. aegylios is reported to be found in the Western Mediterranean and in the Adriatic Sea, where it lives in association with Anemonia viridis (Forsskål, 1775), and occasionally with Condylactis aurantiaca (Delle Chiaje, 1825) (Grippa \& d'Acoz 1996).

Knowledge regarding the lifespan and detailed morphology of larval stages of a species, achievable only through studying reared specimens, is an important tool for understanding the life history of the adult. Larval descriptors are often considered when defining phylogenetic relationships (Ng \& Clark 2000; Felder \& Martin 2003; Anger 2006), particularly if the adults are difficult to distinguish (Ng \& Clark 2000; Cuesta \& Anger 2001). Moreover, the morphological description of larval stages of decapods born in laboratory is an important tool to identify planktonic zoeae.

Previous information on the complete larval development of Periclimenes species is well-documented by dos Santos et al. (2004), who described the Atlantic P. sagittifer from laboratory-reared material. Regarding the 
Mediterranean Periclimenes larvae, Kurian (1956) described Adriatic planktonic zoeae as belonging to the Mesocaris genus; according to the Author they were very similar to the "Palaemonid B.R. V" specimens reported by Gurney (1938). Bourdillon-Casanova (1960) recognized the larvae of Periclimenes in Kurian's description; in turn, she described a sequence of planktonic larval stages (from zoea II to zoea VIII), collected from the Marseille Gulf, as Periclimenes sp., suggesting that they could be ascribable to P. scriptus, due to the likeness between the only eighth stage sampled zoea and the adult of this species. RB, in her unpublished PhD thesis (2005), described and illustrated seven stages of P. aegylios that were laboratory-reared; only a short and brief comparison among the first zoea of $P$. aegylios, $P$. amethysteus, and P. scriptus (the last two species were obtained from ovigerous females) is published (Basile et al. 2005).

Recently, Geiselbrecht \& Melzer (2009) described the first zoea of P. amethysteus, reared in laboratory, with the aid of a scanning electron microscope.

The aim of this work is to re-describe the zoeal stages of Periclimenes aegylios. The description will be used to provide a focus of the genus into the family Palaemonidae, and to make a comparison with the other Mediterranean Periclimenes zoeae described in literature. Furthermore, a comparison with the Atlantic Periclimenes sagittifer will be provided.

\section{Materials and methods}

One ovigerous female Periclimenes aegylios was collected by scuba diving off the Croatian coast (Adriatic Sea, Mediterranean Sea) on August 2000. The female was brought into the laboratory and placed in an aquarium with natural sea water $(\mathrm{S}=35)$. After hatching, swimming larvae were separated from the mother, placed in a small aquarium, and reared en masse $\left(\mathrm{S}=33-35 ; \mathrm{T}=21( \pm 1){ }^{\circ} \mathrm{C}\right.$; photoperiod $=$ natural light-dark regime $)$. Zoeae were fed daily with one-day Artemia salina (Linnaeus, 1758) nauplii, in order to avoid or reduce cannibalism. Every 2 days, dead larvae were removed and fixed in a $4 \%$ buffered solution of formaldehyde in sea water; the exuviae were only partially removed, as they were considered a source of $\mathrm{Ca}^{2+}$ ions for the developing zoeae (G. Pisa, pers. comm.).

The entire specimen (total length, TL, from the tip of the rostrum to the distal margin of the telson plate, and carapace length, CL, from the tip of the rostrum to the posterior margin of carapace) was measured under a light microscope (Nikon Eclipse Euro 2000), equipped with a micrometric eye-piece. Unless otherwise indicated (see Results), ten specimens of each stage were measured. Dissections were performed in glycerine under a Wild Leitz GMBH 020-437.035 stereomicroscope. Body parts and appendages were photographed under the light microscope equipped with a Sony SSC-DC58AP video camera connected to a PC, using the program Matrox PC-VCR Remote. For all dissected appendages, many different photos at different focal levels were used to draw the tiniest details with the highest precision.

Larval descriptions were made following the suggestions of Rice (1979) and Clark et al. (1998).

We considered teeth (on mandibles), spines (pointed), and processes (on maxillipeds and pereiopods) as the structures without basal articulation (Ingle 1992). The setae were distinguishable, according to the length/width ratio and the absence/presence of lateral outgrows, into simple (short or long), plumose, cuspidate (Garm 2004), and serrate (two rows of needle-like outgrowths or denticles, along the seta). The first comb seta under the incisor process of both mandibles was indicated as 'lacinia mobilis', according to Geiselbrecht \& Melzer (2010), who proposed the presence of this structure on both mandibles, not only the left one (Sollaud 1923); the setae between the incisor and molar processes, under the 'lacinia mobilis', were indicated as comb setae - the submarginal setae proposed by Batel et al. (2014).

\section{Results}

The eggs hatched during the night, in September 2000. The last larval stage, zoea VIII, appeared at 31 days after hatching (G. Pisa, pers. comm.).

The first zoeal stage is described in detail. From the second to the eighth stage only the main morphological differences are described and illustrated. 
First zoea (Fig. 1)

Dimensions: $T L=1.84-2.20 \mathrm{~mm}(\mathrm{n}=10 ;$ mean $=2.01$; s.d. $=0.12) ; \mathrm{CL}=0.50-0.60(\mathrm{n}=10 ;$ mean $=0.55$; s.d. $=$ $0.03)$.

Carapace (Fig. 1A): carapace smooth, rostrum slender and scarcely extending beyond the sessile, rounded and sideways-looking eyes, pterigostomial spines present.

Antennule (Fig. 1B): unsegmented peduncle with a long apical plumose seta; external flagellum bearing 4 aesthetascs and 1 plumose seta.
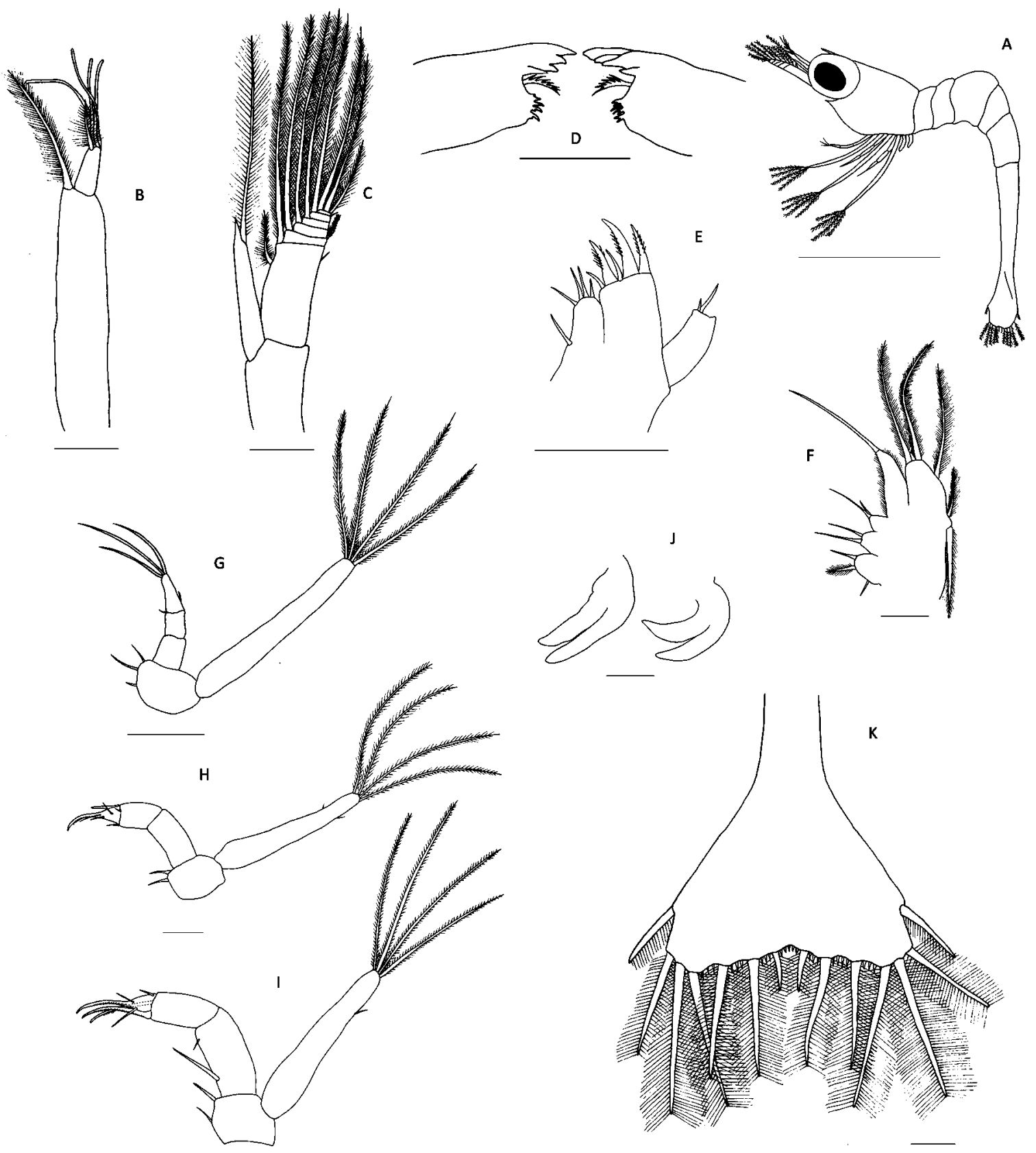

FIGURE 1. Periclimenes aegylios. Zoea I: A Whole larva, lateral view. B Antennule. C Antenna. D Mandibles. E Maxillule. F Maxilla. G First maxilliped. H Second maxilliped. I Third maxilliped. J First and second pereiopods. K Telson. Bar scales: A= $1 \mathrm{~mm} ; \mathrm{B}-\mathrm{K}=0.1 \mathrm{~mm}$. 
Antenna (Fig. 1C): peduncle unarmed; endopod unsegmented, bearing apically 1 short spine and 1 long plumose seta; scaphocerite 6-segmented with 9 internal plumose, 1 small, simple, apical, and 2 external (1 simple and 1 plumose) setae.

Mandibles (Fig. 1D): asymmetrical, palp absent; incisor process with 4 thick teeth on both mandibles; molar process with short teeth arranged as shown; a serrated 'lacinia mobilis' present on both mandibles.

Maxillule (Fig. 1E): coxal endite with 1+4 simple setae; basial endite bearing 2 cuspidate and 3 strong cuspidate spinose setae; endopod with a triangular process on distal end and 2 terminal simple setae of different lengths.

Maxilla (Fig. 1F): coxal endite with 2 simple and 1 plumose setae; basial endite bilobed, with 2 simple setae on each lobe; endopod with 1 long apical simple seta and a row of microtricha on margins; scaphognathite bearing $4+1$ (on proximal lobe) plumose setae.

First maxilliped (Fig. 1G): coxa unarmed; basis with 2 (short) + 1 (long) simple setae; 3-segmented endopod bearing $0,1,1+3$ simple setae, arranged as shown; exopod with 4 apical long plumose setae.

Second maxilliped (Fig. 1H): coxa unarmed; basis with 2 simple setae; 3 -segmented endopod bearing 0, 2 simple and 1 cuspidate setae, 3 simple setae and 1 apical cuspidate spinose process; exopod with 2 distal short simple setae and 4 apical long plumose setae.

Third maxilliped (Fig. 1I): coxa unarmed; basis with 2 simple setae; 3 -segmented endopod bearing 1 (long) +1 (short) simple seta, 2 cuspidate spinose setae, 3 simple setae and 1 apical cuspidate spinose process; exopod with 1 distal short simple and 4 apical long plumose setae.

First pereiopod (Fig. 1J): biramous bud.

Second pereiopod (Fig. 1J): biramous bud.

Third to fifth pereiopods: absent.

Abdomen (Fig. 1A): 5 somites with rounded margins, third somite bigger than the others, the sixth fused with the telson.

Pleopods: absent.

Uropods: absent.

Telson (Fig. 1K): medially indented, setal formula 7+7 (inner 6 setae plumose, the outer one plumose on the internal margin only), with setules between the 4 innermost setae.

\section{Second zoea (Fig. 2)}

Dimensions: $\mathrm{TL}=2.16-2.48 \mathrm{~mm}(\mathrm{n}=10$; mean $=2.24 ; \mathrm{s.d} .=0.11) ; \mathrm{CL}=0.75-0.86 \mathrm{~mm}(\mathrm{n}=10 ;$ mean $=0.78$; s.d.=0.04).

Carapace (Fig. 2A): supraorbital spines present, serrated on ventral margin, rostrum tip reaching the middle of antennule peduncle; eyes stalked.

Antennule (Fig. 2B): 2-segmented peduncle, the distal part of the distal segment with 2 short and 1 long plumose setae; now external flagellum bearing 4 aesthetascs and 1 simple seta.

Antenna (Fig. 2C): endopod with 2 additional simple setae; scaphocerite now 5-segmented, with unchanged setae.

Mandibles (Fig. 2D): incisor process with 3 thick teeth on the left and 4 on the right mandible; 1 comb seta in addition to 'lacinia mobilis'.

Maxillule (Fig. 2E): coxal endite unchanged besides size; basial endite with 3 cuspidate and 4 strong cuspidate spinose setae; endopod without the triangular process.

Maxilla (Fig. 2F): basial endite with a total of 3 simple and 1 plumose setae, arranged as shown; scaphognathite now bearing $6+1$ (on proximal lobe) plumose setae; otherwise unchanged besides size.

First maxilliped (Fig. 2G): 1 additional simple distal seta on the exopod ( +4 apical plumose), otherwise unchanged besides size.

Second maxilliped (Fig. 2H): endopod bearing 0, 1 simple and 1 cuspidate setae, 4 simple setae and 1 apical cuspidate spinose process, otherwise unchanged besides size.

Third maxilliped (Fig. 2I): 4-segmented endopod bearing 1+1 simple, 0, 2 cuspidate spinose, 4 simple setae and 1 apical cuspidate spinose process, otherwise unchanged besides size.

First pereiopod (Fig. 2J): coxa unarmed; basis with 1 long +1 short simple setae; 4-segmented endopod bearing 1 long +1 short simple setae, 0, 2 cuspidate spinose setae, 1 simple seta and 1 apical cuspidate spinose process; exopod with 2 distal simple and 4 apical long plumose setae. 

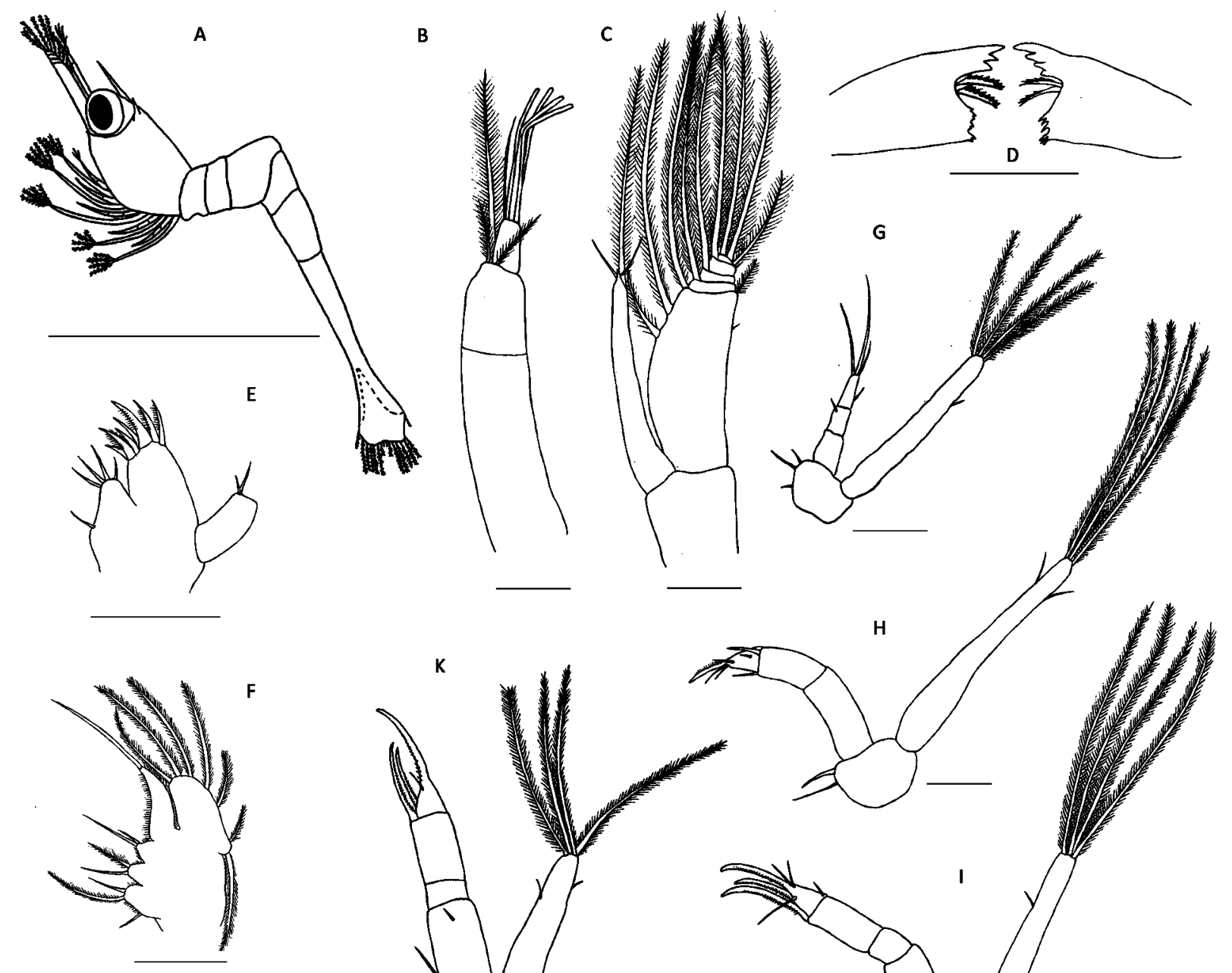

$\mathrm{H}$

K
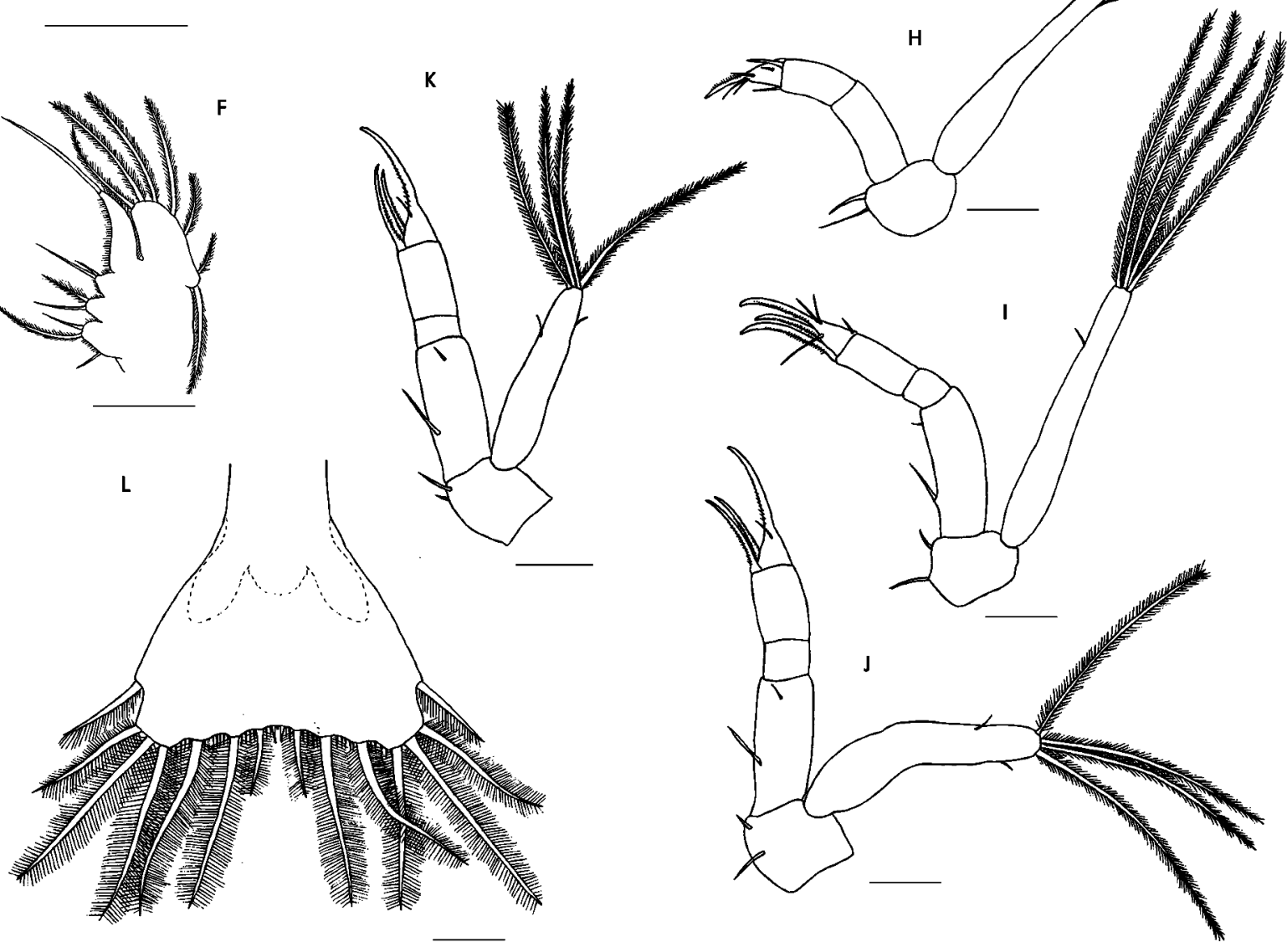

FIGURE 2 Periclimenes aegylios. Zoea II: A Whole larva, lateral view. B Antennule. C Antenna. D Mandibles. E Maxillule. F Maxilla. G First maxilliped. H Second maxilliped. I Third maxilliped. J First pereiopod. K Second pereiopod. L Telson. Bar scales: $\mathrm{A}=1 \mathrm{~mm}$; $\mathrm{B}-\mathrm{L}=0.1 \mathrm{~mm}$.

Second pereiopod (Fig. 2K): number, type, and arrangement of setae, as for the first pereiopod.

Third to fifth pereiopods: absent.

Abdomen (Fig. 2A): unchanged besides size, S-shaped.

Pleopods: absent. 
Uropods: absent.

Telson (Fig. 2L): distal margin slightly concave, setal formula $8+8$.

\section{Third zoea (Fig. 3)}

Dimensions: $\mathrm{TL}=2.40-2.72 \mathrm{~mm}(\mathrm{n}=10$; mean $=2.56$; s.d. $=0.10) ; \mathrm{CL}=0.84-0.95 \mathrm{~mm}(\mathrm{n}=10$; mean $=0.90$; s.d.=0.03).

Carapace (Fig. 3A): unchanged besides size.

Antennule (Fig. 3B): 3-segmented peduncle, the proximal segment with a proximal bulge bearing 1 short plumose seta, 2 medial, 1 subterminal and 3 terminal plumose setae (one very long), the second segment with 3 plumose setae, the distal segment with 3 short plumose setae; internal flagellum with 1 simple seta; external flagellum now with 3 aesthetascs and 1 simple seta.

Antenna (Fig. 3C): 3-segmented endopod now with 4 apical simple setae; scaphocerite 2-segmented with 11 internal plumose ( 8 on the proximal segment, 3 on the distal one), 1 small, simple, apical, and 2 external ( 1 simple and 1 plumose) setae.

Mandibles: unchanged besides size.

Maxillule: unchanged besides size.

Maxilla: unchanged besides size.

First maxilliped: unchanged besides size.

Second maxilliped: unchanged besides size.

Third maxilliped (Fig. 3D): exopod with 1 additional distal simple seta, otherwise unchanged besides size.

First pereiopod (Fig. 3E): 4-segmented endopod bearing 1 long +1 short simple setae, 0,2 (long) +1 (short) cuspidate spinose setae, 1 simple seta and 1 apical cuspidate spinose process; otherwise unchanged besides size.

Second pereiopod: as for the first pereiopod (see Fig. 3E).

Third pereiopod (Fig. 3F): biramous bud.

Fourth to fifth pereiopods: absent.

Abdomen (Fig. 3A): abdominal somite 6 divided from telson, otherwise unchanged besides size.

Pleopods: absent.

Uropods (Fig. 3G): endopod rudimentary and naked; exopod with 6 plumose setae and setules on the internal margin.

Telson (Fig. 3G): setal formula unchanged; the outermost seta naked.

\section{Fourth zoea (Fig. 3)}

Dimensions: $\mathrm{TL}=2.68-3.00 \mathrm{~mm}(\mathrm{n}=10 ;$ mean $=2.85 ; \mathrm{s.d} .=0.11) ; \mathrm{CL}=0.92-1.03 \mathrm{~mm}(\mathrm{n}=10$; mean $=0.98$; s.d.=0.04).

Carapace: dorsal spine at the base of rostrum, serrated on ventral margin (Fig. 3H), otherwise unchanged besides size.

Antennule (Fig. 3I): 3-segmented peduncle, the proximal segment with 1 proximal spine and the proximal bulge now bearing 3 short plumose setae, 1 medial, 5 subterminal and 4 terminal plumose setae ( 1 very long), second segment with 4 plumose setae, distal segment with 3 short plumose setae; internal flagellum with 2 simple setae; external flagellum with 3 aesthetascs and 2 simple setae.

Antenna (Fig. 3J): endopod with 1 additional simple seta on the distal segment; scaphocerite unsegmented, internally and proximally with short setulettes, now bearing 15 (14 long and 1 short) plumose setae, plus an apical spine.

Mandibles (Fig. 3K): now 2 comb setae in addition to 'lacinia mobilis', otherwise unchanged besides size.

Maxillule: unchanged besides size.

Maxilla: unchanged besides size.

First maxilliped: unchanged besides size.

Second maxilliped: unchanged besides size.

Third maxilliped: unchanged besides size.

First pereiopod (Fig. 3L): 4-segmented endopod bearing 1 long +1 short simple setae, 1 simple seta, 3 (long) + 1 (short) cuspidate spinose setae, 1 simple seta and 1 apical cuspidate spinose process; otherwise unchanged besides size. 


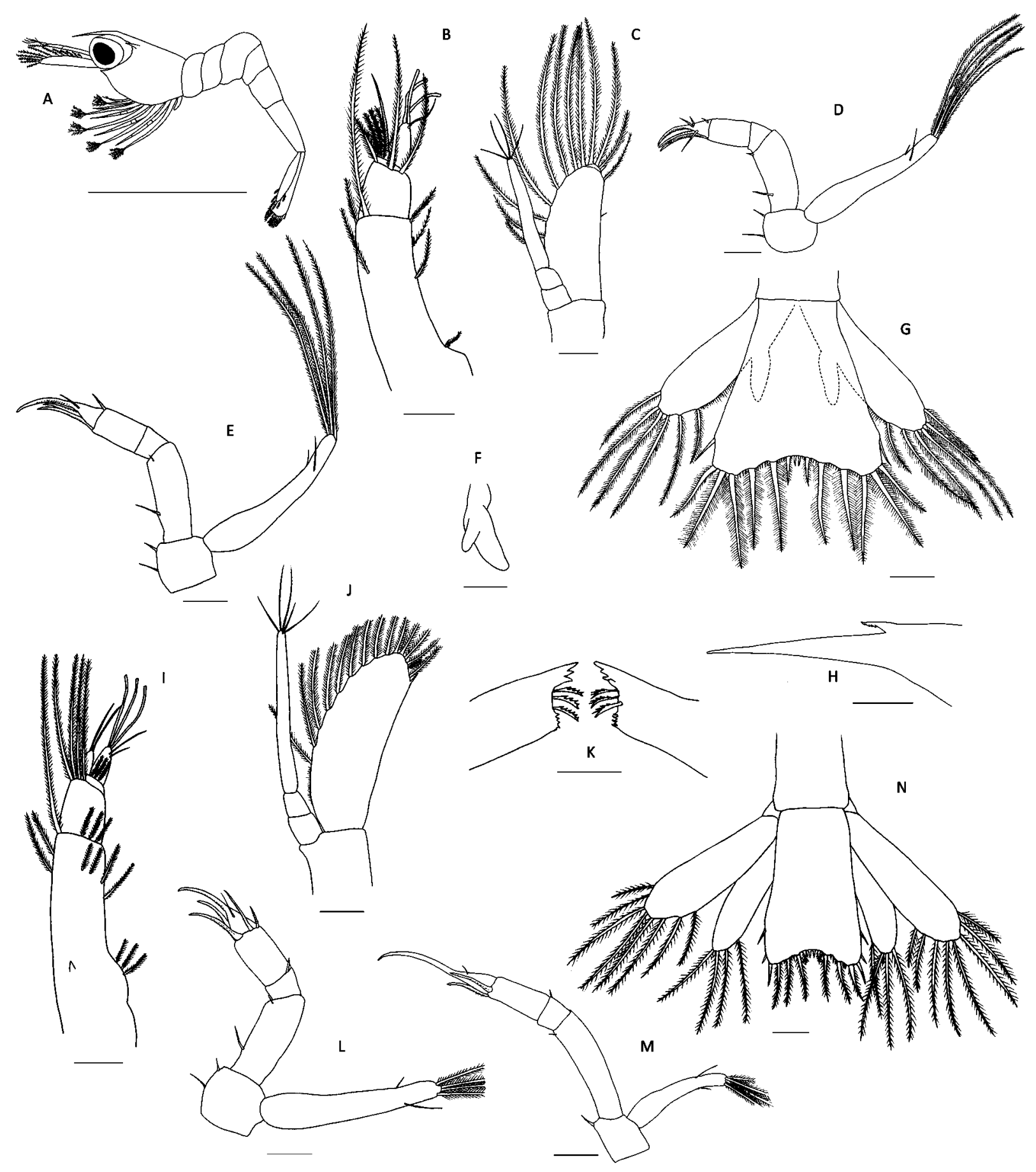

FIGURE 3 Periclimenes aegylios. Zoea III: A Whole larva, lateral view. B Antennule. C Antenna. D Third maxilliped. E First pereiopod. F Third pereiopod. G Telson and uropods. Zoea IV: H Rostrum. I Antennule. J Antenna. K Mandibles. L First pereiopod. $M$ Third pereiopod. $\mathrm{N}$ Telson and uropods. Bar scales: $\mathrm{A}=1 \mathrm{~mm}$; $\mathrm{B}-\mathrm{N}=0.1 \mathrm{~mm}$.

Second pereiopod: as for the first pereiopod (see Fig. 3L).

Third pereiopod (Fig. 3M): coxa unarmed; basis with 1 simple seta; 4-segmented endopod with 1 simple, 1 simple, 2 cuspidate spinose, 1 simple +1 apical cuspidate setae; exopod with 2 distal simple and 4 apical long plumose setae.

Fourth to fifth pereiopods: absent.

Abdomen: unchanged besides size.

Pleopods: absent. 
Uropods (Fig. $3 \mathrm{~N}$ ): as long as telson; endopod and exopod well-developed bearing respectively 4 and 8 plumose setae.

Telson (Fig. 3N): longer and narrower than previous stages (almost rectangular), with 2 spines on each lateral margin and $6+6$ setae on the posterior end.

\section{Fifth zoea (Fig. 4)}

Dimensions: $\mathrm{TL}=2.92-3.80 \mathrm{~mm}(\mathrm{n}=4$; mean $=3.20$; s.d. $=0.41) ; \mathrm{CL}=0.97-1.26 \mathrm{~mm}(\mathrm{n}=4$; mean $=1.06$; .d. $=$ $0.14)$.

Carapace: unchanged besides size.

Antennule (Fig. 4A): 3-segmented peduncle, the proximal segment with 1 proximal spine and the proximal bulge now bearing 4 short plumose setae, 7 medial, 1 subterminal and 4 terminal plumose setae (1 very long), second segment with 4 plumose setae, distal segment with 3 short plumose setae; internal and external flagella unchanged besides size.

Antenna (Fig. 4B): 4-segmented endopod, longer than scaphocerite; scaphocerite bearing 17 plumose setae, plus the apical spine.

Mandibles: unchanged besides size.

Maxillule: unchanged besides size.

Maxilla: unchanged besides size.

First maxilliped: unchanged besides size.

Second maxilliped: unchanged besides size.

Third maxilliped (Fig. 4C): endopod with 1 (short) additional cuspidate spinose seta on segment 3, otherwise unchanged besides size.

First pereiopod: unchanged besides size.

Second pereiopod: unchanged besides size.

Third pereiopod (Fig. 4D): basis now with 1+1 simple setae; 4-segmented endopod with 1+1 simple, 2 simple, $3+1$ cuspidate spinose, 1 simple +1 apical cuspidate setae; exopod unchanged besides size.

Fourth pereiopod (Fig. 4E): biramous bud with a protruding apical process.

Fifth pereiopod (Fig. 4F): uniramous bud with a protruding apical process.

Abdomen: unchanged besides size.

Pleopods: absent.

Uropods (Fig. 4G): slightly longer than the telson; endopod with 9 plumose setae; exopod bearing from external-to-internal margin 1 simple +12 plumose setae.

Telson (Fig. 4G): parallel margins, with 1 spine on each lateral margin and 5+5 setae on the posterior end.

\section{Sixth zoea (Fig. 4)}

Dimensions: $\mathrm{TL}=3.60-4.32 \mathrm{~mm}(\mathrm{n}=10$; mean $=3.78 ; \mathrm{s.d} .=0.23) ; \mathrm{CL}=1.22-1.46 \mathrm{~mm}(\mathrm{n}=10$; mean $=1.28$; s.d.=0.08).

Carapace (Fig. 4H): unchanged besides size.

Antennule (Fig. 4I): 3-segmented peduncle, the proximal segment with 1 proximal spine and the proximal bulge now bearing 8 short setae ( 4 simple, 4 plumose), 13 medial, 1 subterminal and 7 terminal plumose setae (1 very long), second segment with 4 plumose setae, distal segment with 3 short plumose setae; internal and external flagella unchanged besides size.

Antenna (Fig. 4J): endopod unchanged besides size; scaphocerite with an additional plumose seta (18 in total), plus the apical spine.

Mandibles (Fig. 4K): now 3 comb setae in addition to 'lacinia mobilis', otherwise unchanged besides size.

Maxillule (Fig. 4L): basial endite with 3 cuspidate and 5 strong cuspidate spinose setae, otherwise unchanged besides size.

Maxilla (Fig. 4M): coxal endite with 2 plumose and 1 simple setae; basial endite now with 2 simple and 2 plumose setae; scaphognathite with $7+2$ (on proximal lobe) plumose setae; otherwise unchanged besides size.

First maxilliped: unchanged besides size.

Second maxilliped: unchanged besides size.

Third maxilliped: unchanged besides size. 

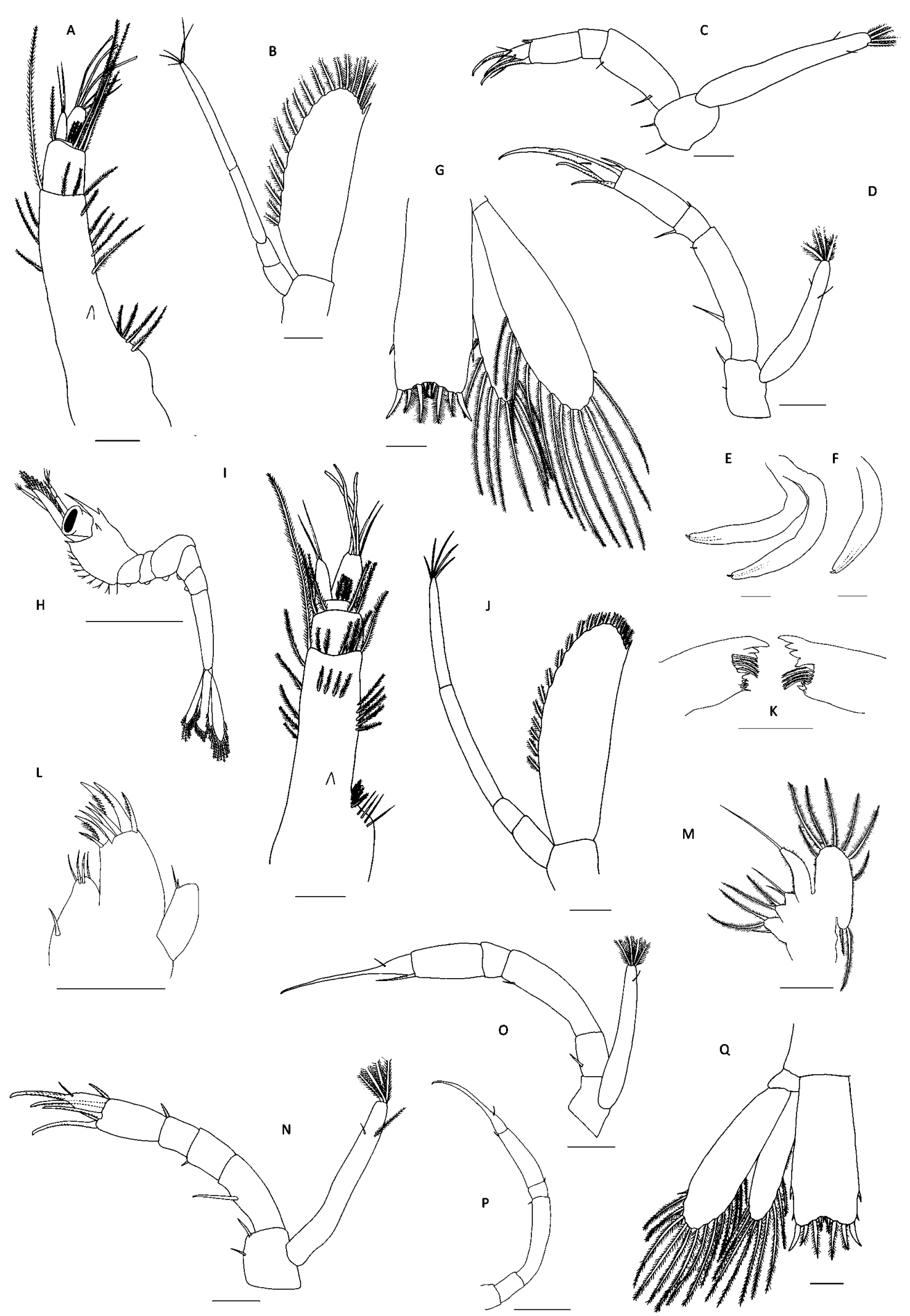

FIGURE 4 Periclimenes aegylios. Zoea V: A Antennule. B Antenna. C Third maxilliped. D Third pereiopod. E Fourth pereiopod. F Fifth pereiopod. G Telson and right uropod. Zoea VI: H Whole larva, lateral view. I Antennule. J Antenna. K Mandibles. L Maxillule. M Maxilla. N First pereiopod. O Fourth pereiopod. P Fifth pereiopod. Q Telson and left uropod. Bar scales: $\mathrm{H}=1 \mathrm{~mm} ; \mathrm{A}-\mathrm{G}, \mathrm{I}-\mathrm{Q}=0.1 \mathrm{~mm}$. 
First pereiopod (Fig. 4N): 5-segmented endopod with 1 simple, 1 simple, 1 cuspidate spinose, $3+1$ cuspidate spinose, 1 simple setae and 1 apical cuspidate spinose process; exopod now with 1 plumose and 1 simple distal setae ( +4 apical plumose); otherwise unchanged besides size.

Second pereiopod: as for the first pereiopod (see Fig. 4N).

Third pereiopod: unchanged besides size.

Fourth pereiopod (Fig. 4O): coxa unarmed; basis unarmed; 5-segmented endopod with 1 simple, 1 simple, 0, 1 cuspidate spinose, 1 simple setae +1 apical cuspidate process; exopod with 1 distal simple +4 apical plumose setae.

Fifth pereiopod (Fig. 4P): uniramous, coxa and basis unarmed; 5-segmented with 0, 1, 1, 1 simple, 1 simple setae +1 apical cuspidate process.

Abdomen (Fig. 4H): unchanged besides size.

Pleopods (Fig. 4H): uniramous buds.

Uropods (Fig. 4Q): 1 additional plumose seta on exopod; otherwise unchanged besides size.

Telson (Fig. 4Q): 2 spines on each lateral margin and 5+5 setae on the posterior end.

\section{Seventh zoea (Fig. 5)}

Dimensions: $\mathrm{TL}=3.84-5.22 \mathrm{~mm}(\mathrm{n}=7$; mean $=4.39$; s.d. $=0.42) ; \mathrm{CL}=1.30-1.77 \mathrm{~mm}(\mathrm{n}=7$; mean=1.49; $\mathrm{s.d} .=$ $0.14)$.

Carapace (Fig. 5A): 1 short plumose seta beneath the dorsal spine (Fig. 5B), otherwise unchanged besides size.

Antennule (Fig. 5C): 3-segmented peduncle, the proximal segment with 1 proximal spine and the proximal bulge bearing 8 short setae ( 4 simple, 4 plumose), 12-15 plumose setae on the third quarter of segment, 1 subterminal and 8-10 terminal plumose setae ( 1 very long), second segment with 4 plumose setae, distal segment with 3 short plumose setae; internal flagellum with 3 simple setae, external flagellum unchanged besides size.

Antenna (Fig. 5D): 5-segmented endopod with 0, 0, 1, 1, 5 simple setae; scaphocerite now with 19 plumose setae, plus the apical spine.

Mandibles (Fig. 5E): now 4 comb setae in addition to 'lacinia mobilis', otherwise unchanged besides size.

Maxillule: unchanged besides size.

Maxilla (Fig. 5F): basial endite with an additional simple seta; scaphognathite with $7+3$ (on proximal lobe) plumose setae; otherwise unchanged besides size.

First maxilliped (Fig. 5G): basis with $4+1$ simple setae, otherwise unchanged besides size.

Second maxilliped: unchanged besides size.

Third maxilliped (Fig. 5H): unchanged basis; endopod now bearing 1 (long) +1 (short) simple, 1 simple, $2+1$ cuspidate spinose, 3 simple setae and 1 apical cuspidate spinose process; on exopod, a plumose seta in place of the simple distal one.

First pereiopod (Fig. 5I): 5-segmented endopod with 1 simple, 1 simple, 1 simple +1 cuspidate spinose, 1 simple $+2+1$ cuspidate spinose, 1 simple setae and 1 apical cuspidate spinose process; segment 4 (propodus) internal distal margin produced forward to about one third of segment 5 (dactylus); exopod now with 1 distal plumose seta in place of the simple one; otherwise unchanged besides size.

Second pereiopod (Fig. 5J): 5 -segmented endopod with 0, 1+3 simple, 2 cuspidate spinose +1 simple, $2+1$ cuspidate spinose +1 simple, 1 simple setae +1 apical cuspidate spinose process; propodus internal distal margin produced forward to about one third of dactylus; otherwise unchanged besides size.

Third pereiopod (Fig. 5K): 4-segmented endopod with $1+1$ simple, $2+1$ simple, $3+1$ cuspidate spinose, 1 simple +1 apical cuspidate setae; exopod with 2 distal ( 1 simple +1 plumose) and 4 apical long plumose setae; otherwise unchanged besides size.

Fourth pereiopod (Fig. 5L): 5-segmented endopod with 1 simple, $1+1$ simple, 1 simple +1 (long) +1 (short) cuspidate, 1 simple +3 cuspidate spinose, 1 simple seta +1 apical cuspidate spinose process; otherwise unchanged besides size.

Fifth pereiopod (Fig. 5M): 5 -segmented with $0,0,1,4$ simple, 1 simple setae +1 apical cuspidate process; otherwise unchanged besides size.

Abdomen (Fig. 5A): unchanged besides size.

Pleopods (Fig. 5N): biramous buds.

Uropods (Fig. 5O): about one third longer than telson; endopod with 17 plumose setae; exopod with 1 simple + 22 plumose setae. 
Telson (Fig. 5O): distal margin slightly narrower than the proximal one; 3 spines on each lateral margin and $5+5$ setae on the posterior end.

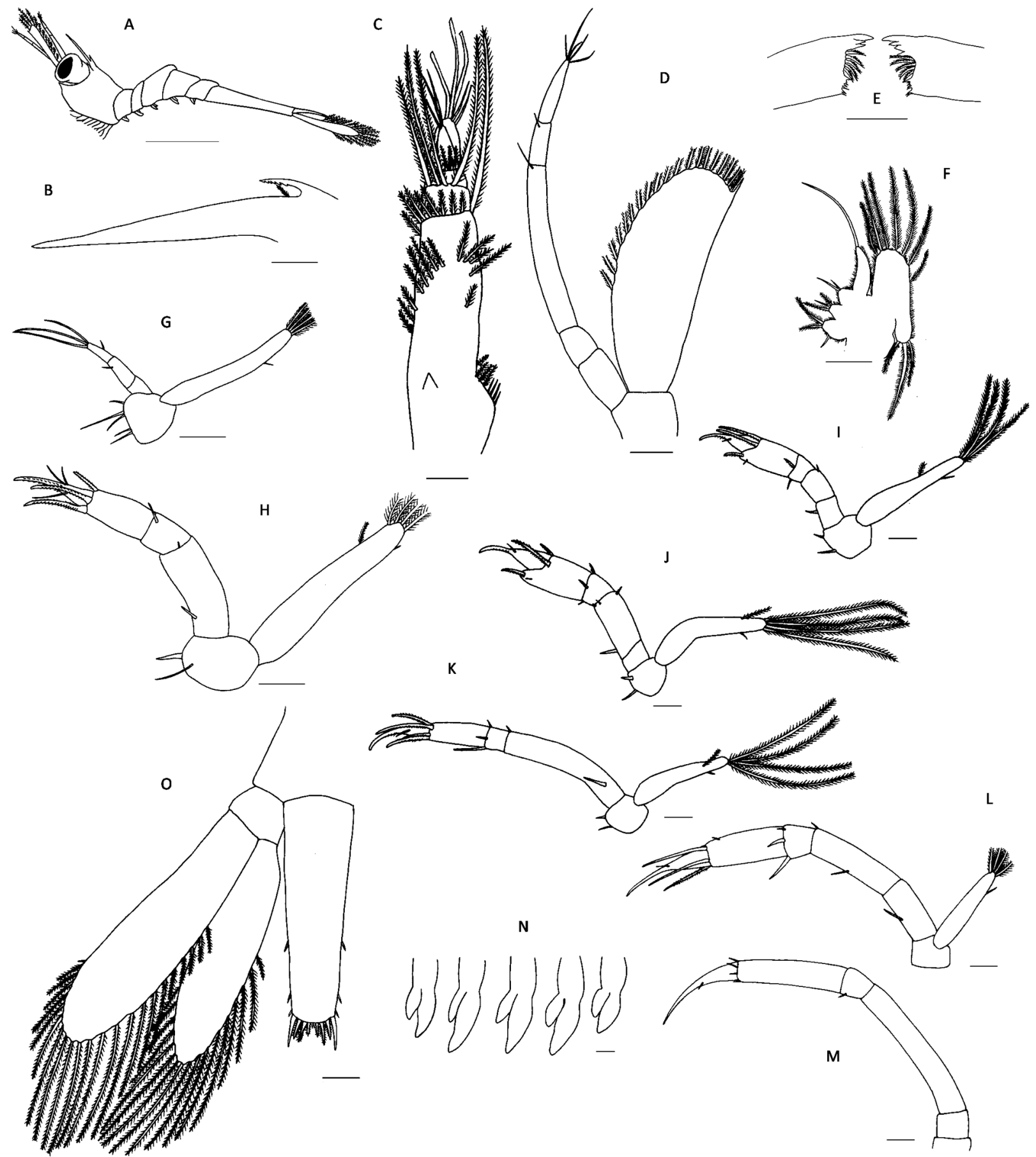

FIGURE 5 Periclimenes aegylios. Zoea VII: A Whole larva, lateral view. B Rostrum. C Antennule. D Antenna. E Mandibles. F Maxilla. G First maxilliped. H Third maxilliped. I First pereiopod. J Second pereiopod. K Third pereiopod. L Fourth pereiopod. M Fifth pereiopod. N Pleopods 1-5. O Telson and left uropod. Bar scales: A=1 mm; B-O=0.1 mm.

Eighth zoea (Fig. 6)

Dimensions: $\mathrm{TL}=4.66-4.70 \mathrm{~mm}(\mathrm{n}=3 ;$ mean=4.68; s.d.=0.02); $\mathrm{CL}=1.60-1.61 \mathrm{~mm}(\mathrm{n}=3 ;$ mean=1.61; s.d.= 0.01).

Carapace (Fig. 6A): unchanged besides size. 

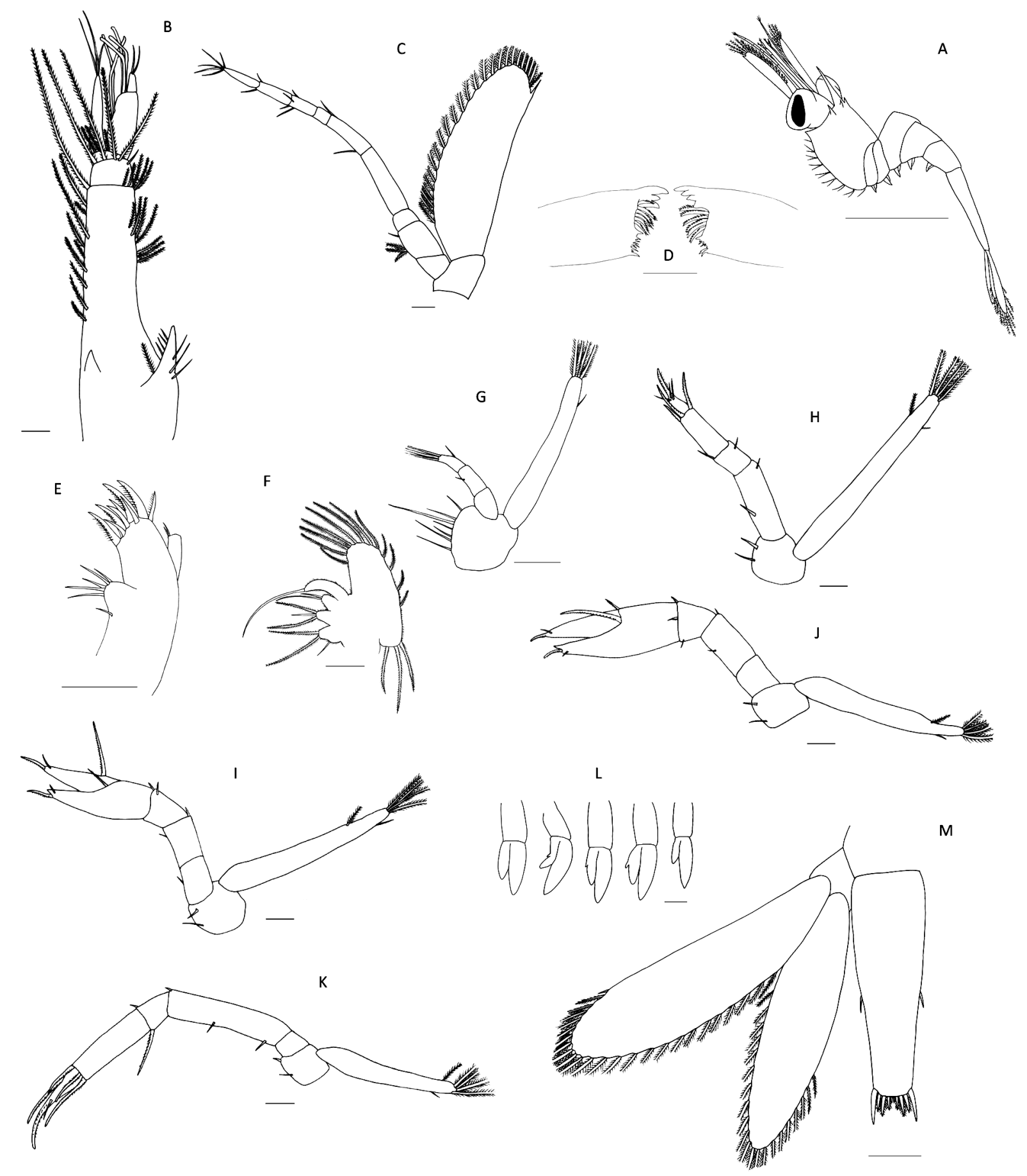

FIGURE 6 Periclimenes aegylios. Zoea VIII: A Whole larva, lateral view. B Antennule. C Antenna. D Mandibles. E Maxillule. F Maxilla. G First maxilliped. H Third maxilliped. I First pereiopod. J Second pereiopod. K Third pereiopod. L Pleopods 1-5. M Telson and left uropod. Bar scales: $\mathrm{A}=1 \mathrm{~mm} ; \mathrm{B}-\mathrm{M}=0.1 \mathrm{~mm}$.

Antennule (Fig. 6B): 3-segmented peduncle, the proximal segment with 1 proximal spine and stylocerite in place of the bulge, bearing 8 short setae (7 simple, 1 plumose), 13-14 medial plumose setae, 2 subterminal and 6-10 terminal plumose setae ( 1 very long), second segment with 4 plumose and 1 short simple setae, distal segment with 3 short plumose setae; internal flagellum unchanged besides size; external flagellum 2-segmented with 2 subterminal and 3 terminal aesthetascs in the proximal segment, and 2 apical short simple setae in the distal segment. 
Antenna (Fig. 6C): 9-segmented endopod with $0,3+1,0,0,2,0,4,2,5$ setae (3 plumose, 14 simple); scaphocerite now with 25 plumose setae, plus the apical spine.

Mandibles (Fig. 6D): now 5 comb setae in addition to the 'lacinia mobilis', otherwise unchanged besides size.

Maxillule (Fig. 6E): basial endite with an additional cuspidate seta, otherwise unchanged besides size.

Maxilla (Fig. 6F): scaphognathite with $12+3$ (on proximal lobe) plumose setae, otherwise unchanged besides size.

First maxilliped (Fig. 6G): basis with 6 short and 1 long simple setae, otherwise unchanged besides size.

Second maxilliped: unchanged besides size.

Third maxilliped (Fig. 6H): segment 2 of endopod with an additional simple seta, otherwise unchanged besides size.

First pereiopod (Fig. 6I): 5-segmented endopod with 1 simple, 1 simple +1 cuspidate spinose, 2 cuspidate spinose, 2 cuspidate spinose +1 simple +1 apical pointed prominence, 1 cuspidate spinose +1 simple +1 apical cuspidate spinose setae; propodus and dactylus forming a rudimentary chela; otherwise unchanged besides size.

Second pereiopod (Fig. 6J): 5-segmented endopod with 0, 2 simple, 2 cuspidate spinose +1 simple, $2+1$ cuspidate spinose setae +1 apical pointed prominence, 1 simple seta +1 apical cuspidate spinose process; propodus and dactylus forming a rudimentary chela; otherwise unchanged besides size.

Third pereiopod (Fig. 6K): endopod now 5-segmented with 0, 3 simple, 1 simple +1 cuspidate spinose, $3+1$ cuspidate spinose, 1 simple seta +1 apical cuspidate spinose process; otherwise unchanged besides size.

Fourth pereiopod: unchanged besides size.

Fifth pereiopod: unchanged besides size.

Abdomen (Fig. 6A): unchanged besides size.

First pleopod (Fig. 6L): biramous bud with protopod.

Second to fourth pleopods (Fig. 6L): biramous buds with protopod, endopod with rudiment of appendix interna.

Fifth pleopod (Fig. 6L): biramous bud with protopod.

Uropods (Fig. 6M): endopod with 21 plumose setae; exopod with 1 simple +24 plumose setae.

Telson (Fig. 6M): distal margin slightly narrower than the proximal one; 1 spine on each lateral margin and $5+5$ setae on the posterior end.

\section{Discussion}

The well-known division of the family Palaemonidae into Palaemoninae and Pontoniinae subfamilies was recently questioned by De Grave et al. (2015) who, through molecular analysis, demonstrated that the two taxa do not form clear monophyletic clades. In order to better compare data regarding larval stages obtained from the literature, we continue to use this distinction. Fincham and Figueras (1986) highlighted the differences among the zoeal stages of the two subfamilies: "Palaemoninae" zoeae show "body straight or abdomen gently curved ventrally" and rostrum longer than the half of the antennular peduncle, whereas in "Pontoniinae" the body has "double bend, rather weakly developed in stage 1" and the rostrum reaches about half length of the antennular peduncle (in stage 1). Moreover, according to dos Santos and Gonzáles-Gordillo (2004), the "Pontoniinae" larva is recognizable thanks to "the dorsal connection between carapace and abdomen" forming a right angle. The features, which allow recognizing the larvae of the "Palaemoninae" species, are well described by Fincham and Figueras (1986). As regards Mediterranean "Pontoniinae", at least the first zoea has been described for six species: Ascidonia flavomaculata (Heller, 1864) (Costanzo et al. 1996), Periclimenes aegylios (present work), Periclimenes amethysteus (Geiselbrecht \& Melzer 2009), Periclimenes scriptus (Basile et al. 2005), Pontonia pinnophylax (Otto, 1821) (Calafiore et al. 1991), Typton spongicola O.G. Costa, 1844 (Lebour 1925). Therefore, it is possible to arrange a key to distinguish the first larval stage of the above-mentioned species, taking into account features of antennule (A1), antenna (A2), maxillule (Mxl), maxilla (Mx) and maxillipeds 1-2 (Mxp1-2):

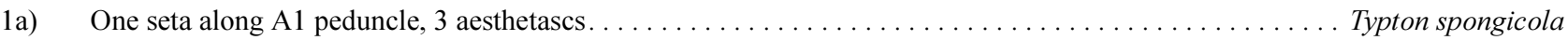

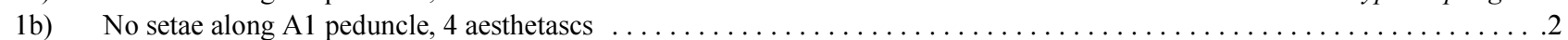

2a) One seta on Mx endopod, 1+2 setae on lobes of Mxl coxal endite ................... Ascidonia flavomaculata

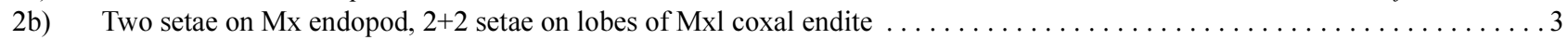


3a) Two simple setae along Mxp 1 exopod; 4-segmented Mxp 2 endopod . . . . . . . . . ........Pontonia pinnophylax

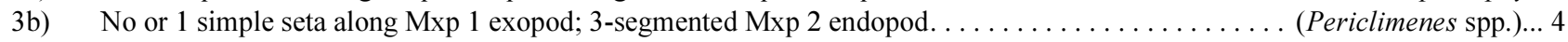

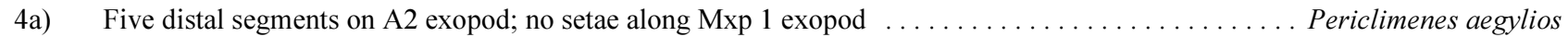

4b) Three or 4 distal segments on A2 exopod; 1 simple seta along the Mxp 1 exopod $\ldots \ldots \ldots \ldots \ldots \ldots \ldots \ldots \ldots \ldots$

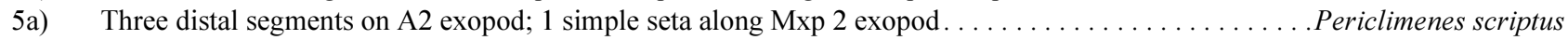

5b) Four distal segments on A2 exopod; 2 simple setae along Mxp 2 exopod . . . . . . . . . . . . . . . Periclimenes amethysteus

Points 4 and 5 of the key suggest that the number of distal segments of antennal exopod is sufficient to distinguish among the Mediterranean Periclimenes species whose larvae are known.

Barnich (1996) attributed some general features to Mediterranean Periclimenes spp. larvae: "S-shaped body, eyes looking sideways, pterigostomial spines present, carapace margin not serrated, supraorbital spines long and serrated on ventral side"; from zoea IV, "rostrum with rostral tooth, the tooth being serrated on ventral side, pereiopod 5 without exopod, abdominal somites $1-5$ with pleopods, telson in young stages triangular, only very slightly invaginated". Nevertheless, in P. aegylios zoea I the typical S-shaped body is scarcely visible. Furthermore, supraorbital spines appear from the second stage, whereas pleopods start to develop from the sixth stage. The absence of the S-shaped body and the supraorbital spines in the first zoeal stage also occurs in P. amethysteus (Geiselbrecht \& Melzer 2009) and P. sagittifer (dos Santos et al. 2004).

Regarding the possible comparison among zoeae II-VIII of P. aegylios (present work) and Periclimenes sp. collected from the plankton by Bourdillon-Casanova (1960), it is useful to note that the Author highlighted that the stages II-VII she described could be ascribable both to P. amethysteus and P. scriptus; only the eighth stage resembles the adult of the second species. Even though the present comparison does not concern all the features, because the Bourdillon-Casanova's description (1960) is not complete, the main features of the distinction between the two species are summarized in an additional file [see Additional file 1]. In general, there are widespread differences. Periclimenes larvae coming from Marseille are bigger than P. aegylios ones; size gap is particularly noticeable in the last stage, which is just over 1.5 times longer than P. aegylios. Another distinctive feature is the presence of antennal spines from the third stage, that are always absent in $P$. aegylios. Other differences regard antennular peduncle, maxillipeds, uropods and telson formula [see Additional file 1]. Moreover, Marseille zoeae show a precocious development of pereiopods and pleopods. Differences in size and development could be ascribable also to the different sources of the specimens under comparison, plankton samples $(P$. sp.) and laboratory-reared material (P. aegylios).

According to Grippa and d'Udekem d'Acoz (1996), the adults of P. aegylios and P. sagittifer form the sagittifer complex. Regarding the zoeae of this complex, almost every stage shows remarkable differences between the two species, also evident without dissecting the specimens (Table 1).

Here too, $P$. aegylios larvae are smaller and show a general retard mainly as regards the development of pereiopods and pleopods, comparing to $P$. sagittifer. Nevertheless, since the first zoea the differences between the two species are appreciable: zoea I of $P$. aegylios can be identified from $P$. sagittifer one because it does not present a distal process on antennular peduncle, it has 5 distal segments (instead of 4 ) and 9 internal plumose setae (instead of 10) on antennal scaphocerite; the endopod of the first maxilliped is 3-segmented (instead of 4-segmented) with a proximal simple seta on the last segment (absent in P. sagittifer); finally, exopod of maxilliped 2 has 2 proximal simple setae (instead of 1 plumose). The differences between the two species go on throughout the zoeal development; since it is problematic to summarize all the differences of all the zoeal stages, characters are listed in Additional file 2, which gives a detailed and readable comparison. It is interesting to highlight two aspects of these differences. The first one is the segmentation of almost all the appendages. Indeed, in $P$. aegylios maxillipeds 1 and 2 endopods appear and remain 3-segmented, while in $P$. sagittifer maxilliped 1 endopod appears 4-segmented and maxilliped 2 endopod becomes 4-segmented from zoea IV. Maxilliped 3 endopod remains 4-segmented since zoea II in P. aegylios, whereas it becomes 5-segmented from zoea V in P. sagittifer. Pereiopods 1 and 2 endopods are 4segmented (5-segmented in $P$. sagittifer) until zoea VI, whereas pereiopod 3 endopod is 4-segmented (5-segmented in P. sagittifer) until zoea VII. The second aspect regards the development of some characters. In P. aegylios, pereiopod 1 and 2 start to develop the chela in zoea VII (zoea VI in P. sagittifer); pereiopods 3 and 4 endopods appear respectively in zoea III and V (zoea II in P. sagittifer), pereiopod 5 appears in zoea V (zoea III in $P$. sagittifer). Pleopods development is also shifted: in P. aegylios pleopod buds appear in zoea VI, becoming biramous in zoea VII and developing protopod and appendix interna (in pleopods 2 to 4 ) in the last zoea, whereas in $P$. sagittifer pleopods develop one stage earlier, starting from zoea $\mathrm{V}$. 


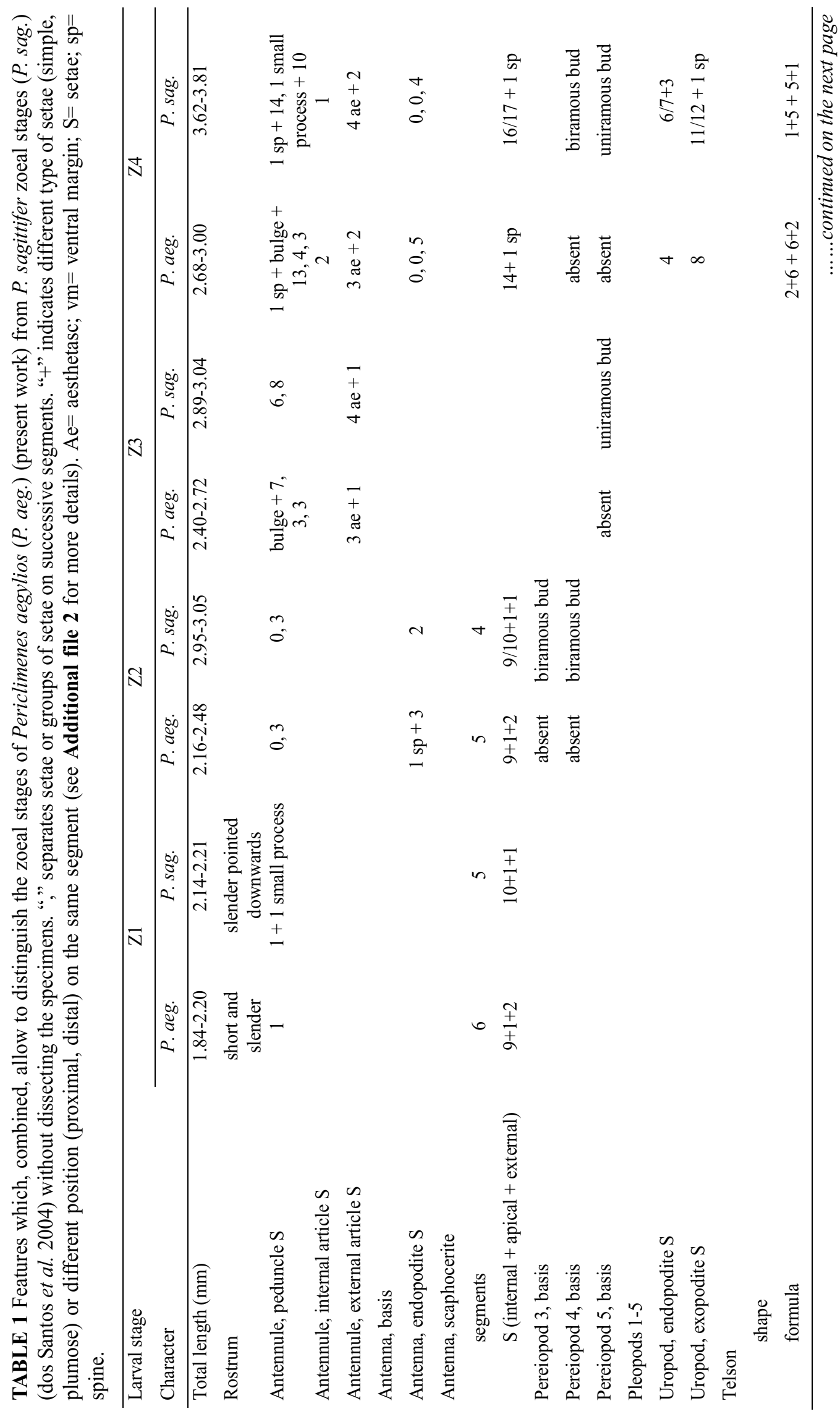




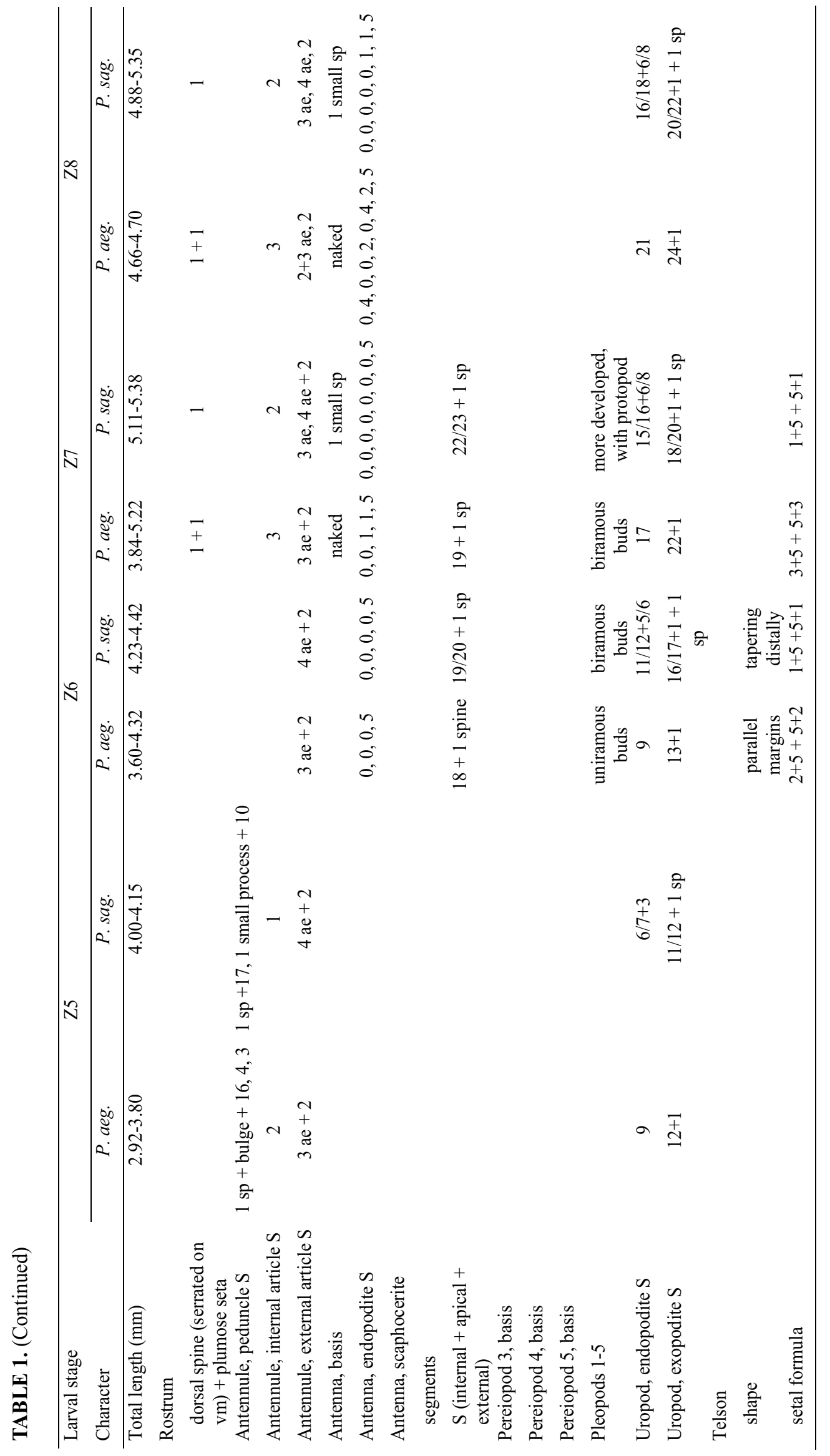


Features persistently different throughout the development are, e.g., the presence of a distal process on maxillular endopod of $P$. sagittifer, which could be detected only in the first zoea of $P$. aegylios, and the bases of pereiopods 4 and 5, which are naked in P. aegylios while with one seta in P. sagittifer. Moreover, the zoeae of the two species show a different uropods setation. Finally, telson of the two species has the same setal formula in the first three stages and in the last one: P. aegylios zoeae IV to VII does not show the usual developmental pattern of setae, found instead in $P$. sagittifer.

The clear morphological distinction detected in larvae supports the separation of the two sagittifer complex species, which was based until now only on the different adults coloration patterns (Grippa \& d'Acoz 1996). In order to better understand the meaning and importance of these above-mentioned differences, larval development of the remaining Mediterranean species of the genus Periclimenes should be investigated.

\section{Acknowledgments}

We thank Giulia Pisa and Gianbruno Grippa for the collection of the ovigerous female of Periclimenes aegylios, and G. Pisa for the rearing of the specimen and the larvae after hatching.

\section{References}

Anger, K. (2001) The biology of decapod crustacean larvae. A.A. Balkema Publishers, Lisse, 419 pp.

Anger, K. (2006) Contributions of larval biology to crustacean research: a review. Invertebrate Reproduction \& Development, 49 (3), 175-205. https://doi.org/10.1080/07924259.2006.9652207

Barnich, R. (1996) The larvae of the crustacea decapoda (excl. Brachyura) in the plankton of the French Mediterranean Coast: identification keys and systematic review. Cuvillier Verlag, Göttingen, 189 pp.

Basile, R., Grippa, G., Pisa, G. \& Pessani, D. (2005) The first larval stage of three species of the genus Periclimenes (Crustacea, Deacapoda). Biologia Marina Mediterranea, 12 (1), 618-620.

Batel, A., Melzer, R.R., Anger, K. \& Geiselbrecht, H. (2014) Heterochrony in mandible development of larval shrimp (Decapoda: Caridea) - A comparative morphological SEM study of two carideans. Journal of morphology, 275 (11), $1258-1272$. https://doi.org/10.1002/jmor.20299

Bourdillon-Casanova, L. (1960) Le méroplancton du Golfe de Marseille: les larves des Crustacés Décapodes. Recueil des Travaux de la Stations Marine d'Endoume, 30, 1-286.

Bruce, A.J., Okuno, J. \& Li, X. (2005) Manipontonia gen. nov., a new pontoniine shrimp genus for Periclimenes psamathe (De Man) (Crustacea: Decapoda: Palaemonidae). Zootaxa, 926 (1), 1-11. https://doi.org/10.11646/zootaxa.926.1.1

Bruce, A. (2007) A re-definition of the genus Periclimenes Costa, 1844 and the designation of a new genus Margitonia (Crustacea: Decapoda: Pontoniinae). Cahiers de Biologie Marine, 48 (4), 403-406.

Calafiore, N., Costanzo, G. \& Giacobbe, S. (1991) Mediterranean species of the genus Pontonia Latreille, 1829. II. Developmental stages of Pontonia flavomaculata Heller, 1864 (Decapoda, Natantia, Pontoniinae) reared in the laboratory. Crustaceana, 60 (1), 52-75. https://doi.org/10.1163/156854096X00790

Clark, P.F., Calazans, D.K. \& Pohle, G.W. (1998) Accuracy and standardization of Brachyuran larval descriptions. Invertebrate Reproduction \& Development, 33 (2-3), 127-144. https://doi.org/10.1080/07924259.1998.9652627

Costanzo, G., Calafiore, N. \& Crescenti, N. (1996) Mediterranean species of the genus Pontonia Latreille, 1829. Developmental stages of Pontonia pinnophylax (Otto, 1821) (Decapoda, Natantia, Pontoniinae) reared in the laboratory. Crustaceana, 69 (6), 773-781. https://doi.org/10.1163/156854091X00263

Cuesta, J.A. \& Anger, K. (2001) Larval morphology of the sesarmid crab Armases angustipes Dana, 1852 (Decapoda, Brachyura, Grapsoidea). Journal of Crustacean Biology, 21 (3), 821-838. https://doi.org/10.1163/20021975-99990175

d'Acoz, C.U. (1999) Inventaire et distribution des crustacés Patrimoines Naturels (Muséum National d'Histoire Naturelle, Service du Patrimoine Naturel, Paris), 40, 1-383. https://doi.org/10.1016/S0990-7440(02)01163-4

De Grave, S. \& Fransen, C.H.J.M. (2011) Carideorum catalogus: the recent species of the dendrobranchiate, stenopodidean, procarididean and caridean shrimps (Crustacea: Decapoda). Zoologische Mededelingen, 85, 195. 
Dos Santos, A., Calado, R., Bartilotti, C. \& Narciso, L. (2004) The larval development of the partner shrimp Periclimenes sagittifer (Norman, 1861) (Decapoda: Caridea: Palaemonidae: Pontoniinae) described from laboratory-reared material, with a note on chemical settlement cues. Helgoland Marine Research, 58 (2), 129-139.

https://doi.org/10.1007/s10152-004-0178-2

Dos Santos, A. \& Gonzáles-Gordillo, J.I. (2004) Illustrated keys for the identification of the Pleocyemata (Crustacea: Decapoda) zoeal stages, from the coastal region of south-western Europe. Journal of the Marine Biological Association of the United Kingdom, 84 (1), 205-227. https://doi.org/10.1017/S0025315404009075h

Felder, D.L. \& Martin, J.W. (2003) Establishment of a new genus for Panopeus bedensis Benedict \& Rathbun, 1891 and several other xanthoid crabs from the Atlantic and Pacific oceans (Crustacea: Decapoda: Xanthoidea). Proceedings of the Biological Society of Washington, 116 (2), 438-452.

Fincham, A.A. (1977) Larval development of British prawns and shrimps (Crustacea: Decapoda: Natantia) - 1 Laboratory methods and a review of Palaemon (Paleander) elegans Rathke 1837. Bulletin of the British Museum (Natural History) Zoology, 32 (1), 1-28.

Fincham, A.A. (1979) Larval development of British prawns and shrimps (Crustacea: Decapoda: Natantia). 3. Palaemon (Palaemon) longirostris H. Milne Edwards, 1837 and the effect of antibiotic on morphogenesis. Bulletin of the British Museum (Natural History) Zoology, 37, 17-46.

Fincham, A.A. (1983) Larval development of British prawns and shrimps (Crustacea: Decapoda: Natantia). 4. Palaemon (Palaemon) serratus (Pennant, 1777) and functional morphology of swimming. Bulletin of the British Museum (Natural History) Zoology, 44, 125-161.

Fincham, A.A. \& Figueras A.J. (1986) Larval keys and diagnoses for the sub family Palaemoninae (Crustacea: Decapoda: Palaemonidae) in the north-east Atlantic and aspects of functional morphology. Journal of natural history, 20 (1), 203-224. https://doi.org/10.1080/00222938600770171

Garm, A. (2004) Revising the definition of the crustacean seta and setal classification systems based on examinations of the mouthpart setae of seven species of decapods. Zoological Journal of the Linnean Society, 142 (2), 233-252. https://doi.org/10.1111/j.1096-3642.2004.00132.x

Geiselbrecht, H. \& Melzer, R.R. (2009) Morphology of the first zoeal stage of the partner shrimp Periclimenes amethysteus Risso, 1827 (Decapoda: Caridea: Palaemonidae: Pontoniinae) studied with the Scanning EM. Zootaxa, 2140, 45-55.

Geiselbrecht, H. \& Melzer, R.R. (2010) Mandibles of zoea I larvae of nine decapod species: a scanning EM analysis. Spixiana, 33 (1), 27-47.

Grippa, G.B. \& d'Acoz, C.U. (1996) The genus Periclimenes Costa, 1844 in the Mediterranean Sea and the Northeastern Atlantic Ocean: review of the species and description of Periclimenes sagittifer aegylios subsp. nov. (Crustacea, Decapoda, Caridea, Pontoniinae). Atti della Societ Italiana di Scienze Naturali e del Museo Civico di Storia naturale di Milano, 135 (2), 401-412.

Gurney, R. (1938) The larvae of the decapod Crustacea. Palaemonidae and Alpheidae. British Museum, 6 (1), 1-60.

Ingle, R.W. (1992) Larval Stages of Northeastern Atlantic Crabs. Chapman \& Hall, London, 363 pp. https://doi.org/10.1017/S0025315400037917

Koukouras, A. \& Türkay, M. (1996) A new species of Periclimenes from the Aegean Sea (Crustacea: Decapoda: Palaemonidae). Senckenbergiana Biologica, 76, 135-144.

Kurian, C.V. (1956) Larvae of decapod Crustacea from the Adriatic Sea. Acta Adriatica, 6 (3), 1-108.

Lebour, M.V. (1925) The eggs and newly hatched larva of Typton spongicola O. G. Costa. Journal of the Marine Biological Association of the United Kingdom, 13 (4), 848-853. https://doi.org/10.1017/S0025315400009280

Li, X. (2009) Sandimenes nov. gen., for Periclimenes hirsutus Bruce, 1971 (Decapoda, Caridea, Pontoniinae). Crustaceana, 82 (7), 881-896. https://doi.org/10.1163/156854009X427414

Ng, P.K. \& Clark, P.F. (2000) The eumedonid file: a case study of systematic compatibility using larval and adult characters (Crustacea: Decapoda: Brachyura). Invertebrate Reproduction \& Development, 38 (3), 225-252. https://doi.org/10.1080/07924259.2000.9652457

Rice, A.L. (1979) A plea for improved standards in descriptions of crab zoeae. Crustaceana, 37 (2), 214-218. https://doi.org/10.1163/156854079X01040

Sollaud, E. (1923) Le développement larvaires des "Palaemoninae. Bulletin biologique de la France et de la Belgique, 57, 509-603.

Williamson, D.I. (1982) Larval morphology and diversity. In: Abele, L.G. (Ed.), The Biology of Crustacea: 2. Embryology, morphology and genetics. Academic Press, New York, pp. 43-110. 


\section{Additional file 1}

Main features distinguishing the zoeae II-VIII of P. aegylios (P. aeg.) (present work) from the Periclimenes sp. $(P$. sp.) zoeae (Bourdillon-Casanova 1960). $\mathrm{A} 1=$ antennule; $\mathrm{Ae}=$ aesthetasc; $\mathrm{ap}=$ apical; $\mathrm{cusp}=$ cuspidate; $\mathrm{ext}=\mathrm{external}$; int $=\mathrm{internal} ; \mathrm{pl}=$ plumose; $\mathrm{s}=$ simple; $\mathrm{S}=$ seta; segm= segment/segmented; $\mathrm{sp}=$ spinose; subt= subterminal; term= terminal; $\mathrm{vm=}$ ventral margin .

\section{Additional file 2}

Comparison regarding size and morphological features among zoeae I-VIII of Periclimenes aegylios ( $P$. aeg.) (present work) and $P$. sagittifer (P. sag.) (dos Santos et al. 2004). A1= antennule; Ae= aesthetasc; ap= apical; cusp= cuspidate; ext=external; int= internal; $\mathrm{pl}=$ plumose; $\mathrm{s}=$ simple; $\mathrm{S}=$ seta; segm= segment/segmented; $\mathrm{s} p=$ spinose; $\mathrm{vm}=$ ventral margin. 